\title{
Reproductive biology and energetics of the brooding sea star Anasterias antarctica (Echinodermata: Asteroidea) in the Beagle Channel, Tierra del Fuego, Argentina
}

\author{
Analía F. Pérez ${ }^{1}$, Cintia Fraysse ${ }^{1}$, Claudia C. Boy ${ }^{2}$, Lucia Epherra $^{3}$ \& Calcagno Javier ${ }^{1}$ \\ 1. Laboratorio de Invertebrados Marinos. CEBBAD. Universidad Maimónides - CONICET, Ciudad de Buenos Aires, \\ Argentina. analiafperez1@gmail.com \\ 2. Laboratorio de Ecología, Fisiología y Evolución de Organismos Acuáticos. CADIC - CONICET, Ushuaia, Argentina. \\ 3. IDEAus - CENPAT - Consejo Nacional de Investigaciones Científicas y Técnicas (CONICET), Puerto Madryn, \\ Argentina.
}

Received 08-XII-2016. Corrected 05-VIII-2017. Accepted 23-VI-2017.

\begin{abstract}
The brooding sea star Anasterias antarctica is distributed from the coast of Patagonia to the northern Peninsula of Antarctica. In the Beagle Channel, the females of $A$. antarctica brood their eggs for seven months and do not feed during this period. The endoparasite Dendrogaster argentinensis (Crustacea: Ascothoracica) causes castration in several species of Anasterias. We randomly collected four samplings of adults in May, August and October (brooding period) and January (non-brooding period). The gonad (GI) and pyloric caeca index (PCI) were calculated as organ wet weight $(\mathrm{g})$ x 100/total wet weight $(\mathrm{g})$. Each individual was sexed by microscopic examination of the gonads. Sex ratio, brooding females/non-brooding females and mature females/ non-mature females ratios was 1:1. The male GI reached maximum values in January, when most individuals were sexually mature. The GI of non-brooding females reached its maximum during October when it was significantly higher than those from brooding females. The PCI was minimum in October, being lower in brooding females (August and October). During the non-brooding period, mature females had a significantly higher GI than non-mature females. The PCI did not vary neither between males, nor between mature and non mature females. By the end of the brooding period, non-brooding females showed a higher GI than the brooding females. This is explained by proliferation and increase of the oocytes size of non-brooding females. Mature females showed an incremented GI with presence of mature oocytes, while non-mature females exhibited more abundance of previtelogenic oocytes. Males showed synchronicity in reproductive condition. The females that have not brooded presented a process of active gametogenesis, reaching the summer with a high GI, therefore becoming mature females. Females that had brooded were probably lacking energy for new gonadal maturation. The pyloric caeca would be performing the role of a reserve organ in the brooding females, decreasing its size during the brooding period. Prevalence of D. argentinensis in A. antarctica was $11.06 \%$. As this parasite was recorded in sea stars lacking gonads, these infected hosts could have been castrated. Rev. Biol. Trop. 65(Suppl. 1): S221-S232. Epub 2017 November 01.
\end{abstract}

Key words: brooding sea star; gonad; pyloric caeca; reserve organ; endoparasite.

The reproductive strategies of echinoderms have been widely discussed, especially with regard to the importance of incubation and parental care (Gillespie \& McClintock, 2007). Most sea stars produce planktotrophic or lecithotrophic pelagic larvae that disperse widely (Chia \& Walker, 1991). On the other hand, a small number of species produce lecithotrophic non-pelagic embryos that are usually incubated by females. For example, Leptasterias polaris (Himmelman, Lavergne, Cardinal, \& Jalbert, 1982; Hamel \& Mercier, 1995) and Asterina phylactica (Strathmann, Strathmann \& Emson, 1984) protect their embryos under their body, while L. hexactis (Chia, 1968), L. ochotensis (Kubo, 1951), A. antarctica (Pérez, Boy, Calcagno \& Malanga, 2015) and Anasterias minuta (Salvat, 1985; Gil \& Zaixso, 2007) arch their 
arms to create an incubation chamber. Anasterias minuta is a junior synonym of Anasterias antartica, according to (Clark \& Downey, 1992; Romanelli-Michel, 2014).

Echinoderms usually exhibit a seasonal cycle in activities such as feeding, growth and reproduction (Brockington, Clarke \& Chapman, 2001; Gil \& Zaixso, 2007; Pérez, Morriconi, Boy \& Calvo, 2008; Cossi, Boy, Giménez \& Pérez, 2015) (Brockington, Clarke, \& Chapman, 2001; Gil \& Zaixso, 2007; Pérez, Morriconi, Boy, \& Calvo, 2008; Cossi, Boy, Giménez, \& Pérez, 2015). Gonadal development is closely related with nutrient input (Lawrence, 1987b) although ingested energy must be partitioned among organism growth and maintenance as well (Lucas, 1996). This differential allocation may vary between sexes and phase of the reproductive cycle (Lawrence \& McClintock, 1994).

Moreover, reproductive effort varies with the mode of development (Pérez et al., 2015). Generally, species with indirect development (with larvae), reproductive investment is usually equal between sexes (Raymond, Himmelman \& Guderley, 2007; Mariante, Lemos, Eutrópio, Castro \& Gomes, 2010). In species with direct development, reproductive effort differs between sexes. Normally, males invest more energy to gametes production than females, but females face the additional cost of incubating embryos (Raymond, Himmelman \& Guderley, 2004; Gillespie \& McClintock, 2007; Pérez et al., 2015). The pyloric caeca work as a reserve of energy, located inside the arms and the size and concentration of lipid are indicative of the energy reserves of the individual (Lawrence, 1987a). Some asteroids show an inverse relationship between gonadal and pyloric caeca mass variation cycles due to the transference of material towards the developing gonads (Chia \& Walker, 1991), which changes the proximal composition of both organs during the reproductive cycle (Barker \& Xu, 1991).

The oral-brooding sea star Anasterias antarctica (Lütken, 1857) is widely distributed on the coasts of South Patagonia and northern
Peninsula Antarctica, and occurs from the intertidal zone to $150 \mathrm{~m}$ depth (Bernasconi, 1964). This sea star is a common predator of intertidal and shallow sub littoral communities in Tierra del Fuego, feeding mainly on the mussel Mytilus chilensis and the gastropods Pareuthria plumbea and Trophon geversianus (Curelovich, 2012) and is commonly observed in the intertidal zone during low tide (Pérez et al., 2015). The females of $A$. antarctica of Beagle Channel, brood their eggs in the oral surface for seven months (Pérez et al., 2015) and do not feed during this period (Pérez personal obsevation), as it was also documented for Golfo San Jorge and Puerto Deseado (Patagonia, Argentina) (Gil \& Zaixso, 2008; Gil, Escudera, \& Zaixso 2011) and Malvinas Islands (Laptikhovsky, Brickle, Söffker, Davidson, Roux, Rexer-Huber, Brewin, Kälkvist, Brown, Brown, Black, Anders, Cartwright, Poncet \& Parker, 2015). Other species of sea stars such as Anasterias rupicola, from Marion Island (Southern Ocean), feed during brooding (Blankley \& Branch, 1984). In Pérez et al. (2015) males reproductive effort was found to be $25 \%$ lower than that of females, probably due to brooding costs. Gonadal maturation was recorded in summer and gametogenesis in winter in both sexes (Pérez et al., 2015).

The endoparasite Dendrogaster argentinensis (Crustacea, Ascothoracica) has been recorded in the coelomic cavity of Anasterias antarctica (Grygier \& Salvat, 1984; Grygier, 1986). Generally, parasites impact marine ecosystems decreasing fertility, and altering growth, mortality and behavior of their hosts and also indirectly increasing possibility of predation on parasitized organisms (Lafferty, Dobson \& Kuris, 2006; Dunne et al., 2013). In Ría de Puerto Deseado (Santa Cruz, Argentina), the prevalence of $D$. argentinensis in $A$. antarctica had no apparent effects on different organs (Salvat, 1985). However, an infected individual presented atrophied pyloric caeca which could be due to lack of available space (Grygier \& Salvat, 1984; Salvat, 1985). In Allostichaster insignis in Otago, New Zeland, D. argentinensis can castrate its host indirectly 
through crowding and/or competitive castration (Palmer, 2009), although this was not recorded so far in A. antarctica.

The aim of this study was to expand knowledge on the reproductive biology and energetic of the brooding sea star Anasterias antarctica along its reproductive cycle. A second aim was to study the prevalence presence parasite $D$. argentinensis on $A$. antarctica.

\section{MATERIAL AND METHODS}

Sampling and processing: Anasterias antarctica measuring $>20 \mathrm{~mm}$ in radius were randomly collected every two meters along the parallel transect in the intertidal zone of Ensenada Zaratiegui, Tierra del Fuego National Park, Beagle Channel (5451'00,14" S, $68^{\circ} 29^{\prime} 38,79^{\prime \prime}$ W; Fig. 1). Considering the brooding period of $A$. antarctica was established four collections were made during 2009 and 2010: three of them during the brooding period: (1) on 28 May 2009, at the beginning of brooding, when oocytes are on early stages of maturity; (2) on 21 August 2009, in the middle of the brooding period, when embryo are on advanced maturity; and (3) on 19 October 2009, at the end of brooding (Fig. 2). The fourth collection corresponded with the nonbrooding period (28 January 2010). Seasonal samples of 30 individuals were taken. January sampling was used as an indicator of the nonbrooding period. The specimens collected were transported to the Laboratorio de Ecología, Fisiología y Evolución de Organismos Acuáticos from the Centro Austral de Investigaciones Científicas-CONICET (Ushuaia, Argentina) for subsequent processing. Prior to dissection, each individual was superficially dried with absorbent paper, weighed (total weight, $\pm 0.01 \mathrm{~g}$ ), and the distance from the tip of the longest arm to the opposite interradius (length) was measured using an electronic caliper $( \pm 0.1 \mathrm{~mm})$. Animals were then dissected and gonads and pyloric caeca (digestive glands) were weighed separately $( \pm 0.01 \mathrm{~g})$. The indexes of different

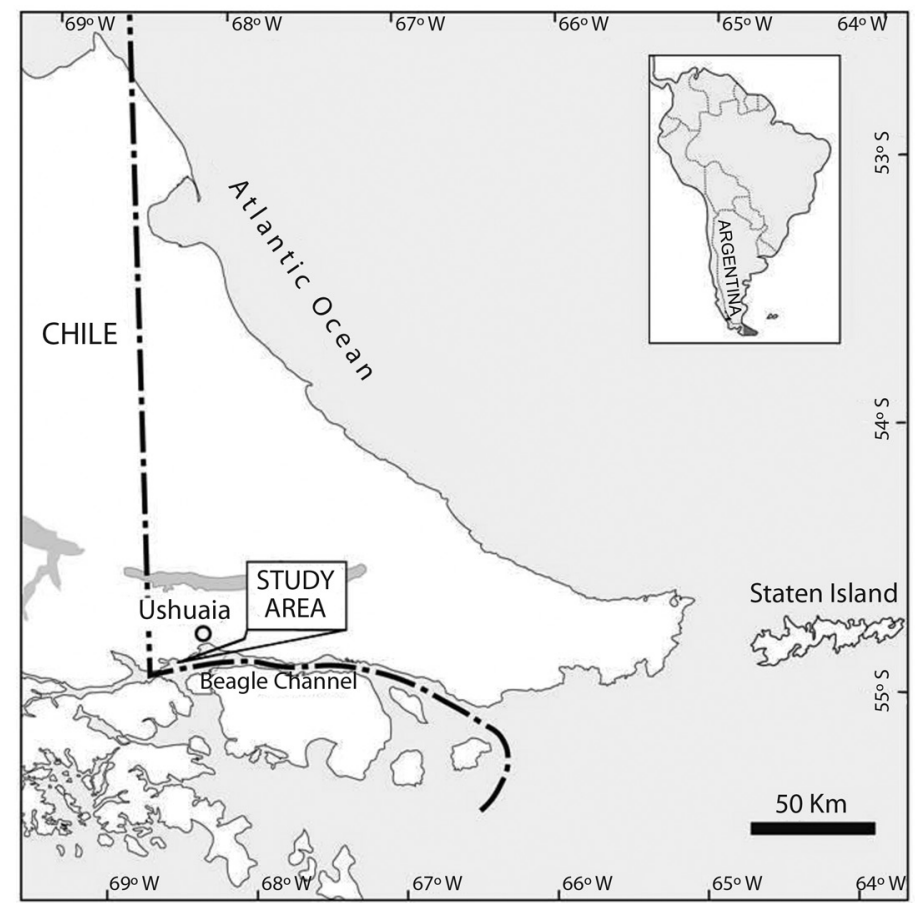

Fig. 1. Study area in Ensenada Zaratiegui, Tierra del Fuego National Park, Tierra del Fuego, Argentina.

Fig. 1. Área de estudio en Ensenada Zaratiegui, Parque Nacional Tierra del Fuego, Tierra del Fuego, Argentina. 

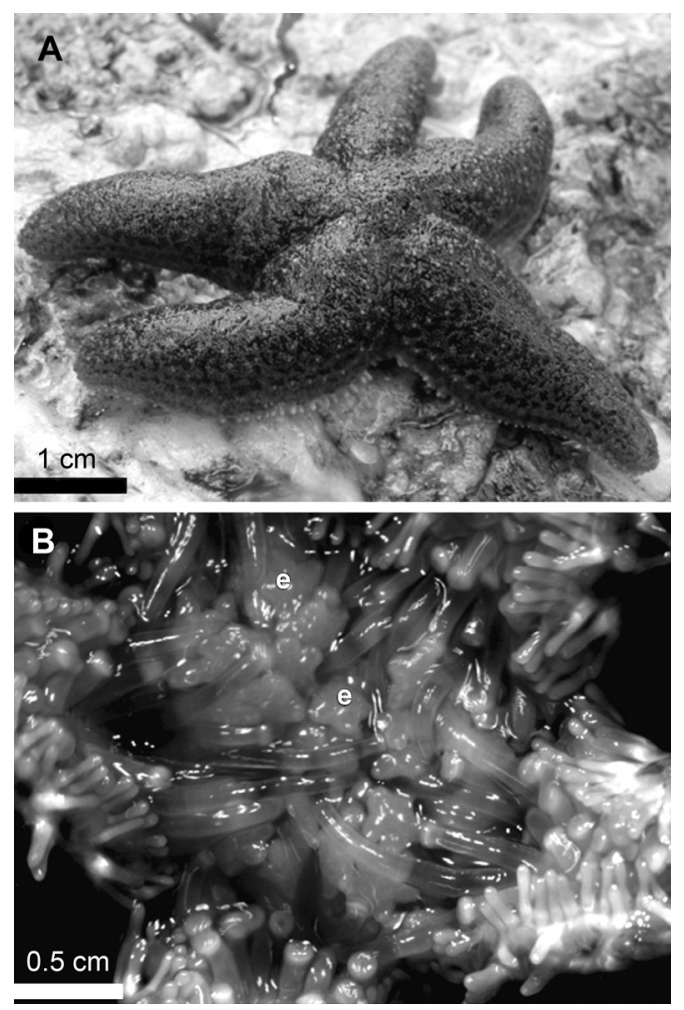

Fig. 2. Anasterias antarctica. A, Adult sea star in the intertidal zone; B, Adult female sea star showing its brood in the oral area. e: embryos.

Fig. 2. Anasterias antarctica. A, Estrella de mar adulta en la zona intermareal; B, Hembra de estrella de mar adulta incubando los embriones en el área oral. E: embriones.

body components (GI: gonad index and PCI: pyloric caeca index) were calculated as organ wet weight (g) x 100/total wet weight (g). GI values were partially published in Pérez et al. (2015). Gonad and pyloric caeca indexes were computed as an indicator of energy reserves stored in these organs (Lloret \& Planes, 2003).

Histological determinations: The slides were prepared from a one gonad of each specimen was fixed in Bouin's solution for $12 \mathrm{~h}$, then washed in water prior to transfer to $70 \%$ alcohol and then dehydrated in a graded ethanol series. Gonads was embedded in liquid paraffin (Paraplast ${ }^{\circledR}$ ), sectioned at 5-7 $\mu \mathrm{m}$ (microtome Leica RM2125RT) and stained with Carazzi's hematoxylin and eosin (Pérez et al., 2008). Sections were examined microscopically and each individual was sexed. Individuals sampled during the brooding period were assigned to one of three groups: brooding females, non-brooding females, and males. Individuals sampled during the non-brooding period were assigned to one of three groups: sexually mature females, non-mature females and males. The individuals without gonads were excluded from the analyses.

\section{Occurrence of Dendrogaster argentinen-} sis: In parasitized specimens with $D$. argentinensis, the parasite was carefully extracted under stereoscopic magnifying glass (10x). The prevalence of infection was estimated according to Bush, Lafferty, Lotz \& Shostak (1997) as the percentage of parasitized specimens by total individuals, sex and female gonadal stages.

The sex ratio and reproductive condition were determined by examining histological slides in all individuals collected throughout the study. The sex ratio was tested using a goodness of fit $(\mathrm{G})$ test, with equal sex ratios as null hypothesis (Sokal \& Rohlf, 1995). The individuals without gonads were exclude from the analyses.

In males, seasonal variations in GI were analyzed using a Kruskal-Wallis test followed by unplanned Dunn's multiple comparisons test. The variations in PCI were analyzed using one-way ANOVA, followed by Tukey HSD comparisons.

The GI and PCI of females sampled during the brooding period were analyzed using a twoway ANOVA to test for differences between period (May, August and October) and reproductive condition (brooding and non-brooding females). Pair-wise differences between periods were analyzed by unplanned Tukey HSD.

In females sampled during the non-brooding period (January), differences in GI and PCI between mature and non-mature females were tested using the unpaired $t$ test.

Assumptions of normality (KolmogorovSmirnov test) and homogeneity of variances (Bartlett test) were previously verified for PCI of males, and GI and PCI of females during 
the brooding and non-brooding period. The log transformation was applied for GI of females during non-brooding period. In case of the assumptions were not validated, a nonparametric test was used (Zar, 1984).

Correlation between GI and PCI were studied through Pearson correlations (Zar, 1984).

Statistical analyses were performed using STATISTICA 6.0 Package (Statsoft Inc. 1998).

\section{RESULTS}

Sex ratio, brooding females/non-brooding females and mature females/non-mature females ratios did not differ significantly from 1:1 (Test $\mathrm{G}, \mathrm{P}>0.05$ in all cases).

Males: The male GI varied significantly between periods (Kruskal-Wallis Test, $\mathrm{H}=$ $31097, \mathrm{P}<0.0001$ ), reaching maximum values in January (Fig. 3A), determining histologically that most of the individuals were sexually mature. On the other hand PCI did not vary significantly between periods (one-way ANOVA, $\mathrm{F}_{3,42}=0.6174, \mathrm{P}>0.05$ ) (Fig. 3B). Finally, GI and PCI were not correlated (r: 0.29, $\mathrm{P}>0.05$ ).

Females brooding period: For GI, the interaction between period and reproductive conditions was not significant (two-way ANOVA, $\left.\mathrm{F}_{2,38}=2.3209, \mathrm{P}>0.05\right)$. On the other hand, the GI of non-brooding females reached its maximum in October when it was significantly higher than those of brooding females (Simple effect, $\mathrm{P}<0.05$ ) (Fig. 4A). For PCI, the interaction between period and reproductive conditions was not significant (two-way ANOVA, $\mathrm{F}_{2,46}=0.5765, \mathrm{P}>0.05$ ) (Fig. 4B). The PCI was minimum in October (Simple effect, $\mathrm{P}<0.05$ ) and were lower in brooding females than non-brooding females (August and October). The correlation between GI and PCI was not significant for brooding ( $\mathrm{r}: 0.047 ; \mathrm{P}>0.05$ ) and non-brooding females ( $\mathrm{r}: 0.018, \mathrm{P}>0.05$ ).

Females non-brooding period: Mature females had a significantly higher GI than non-mature females (Unpaired $\mathrm{t}$ test, $\mathrm{t}_{1,10}=$
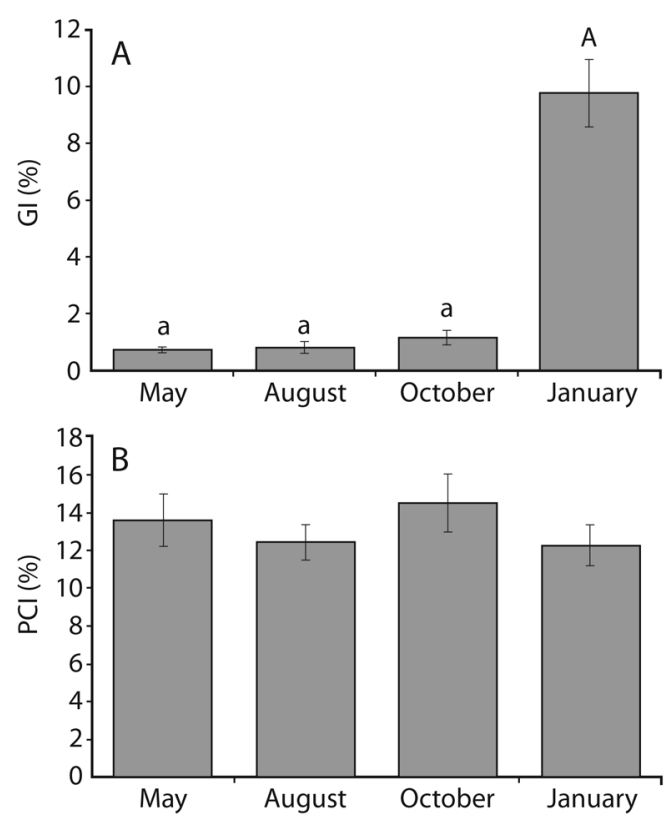

Fig. 3. Seasonal variation in males of Anasterias antarctica. A, Gonad index (GI) (Pérez et al., 2015); B, Pyloric caeca index (PCI). Mean and SEM (Barr= standard error of mean). Only significant differences are indicated by the same capital and small letter.

Fig. 3. Variación estacional en machos de Anasterias antarctica. A, Índice gonadal (GI) (Pérez et al., 2015); B, Índice de ciego pilórico (PCI). Media y ESM (Barra= error estándar de la media). Solo las diferencias significativas son indicadas con pares de la misma letra, en minúscula y mayúscula.

8441, $\mathrm{P}<0.05$ ) (Fig. 5A). The PCI did not vary significantly between mature and non-mature females (Unpaired t test, $\mathrm{t}_{1,11}=0.4238, \mathrm{P}>0.05$ ) (Fig. 5B). The correlation between GI and PCI was not significant (r: 0.019; $\mathrm{P}>0.05$ ).

Histology of gonads: Females sampled during the non-brooding period were divided in two groups: sexually mature females and non-mature females.

The ovaries of mature females contain numerous mature ova with acidophilic cytoplasm, densely packed into the lumen and small number of previtellogenic oocytes located along the acinus wall (Fig. 6A). Non-mature females present along acinus wall oogonias, previtellogenic oocytes and small vitellogenic oocytes (Fig. 6B). 

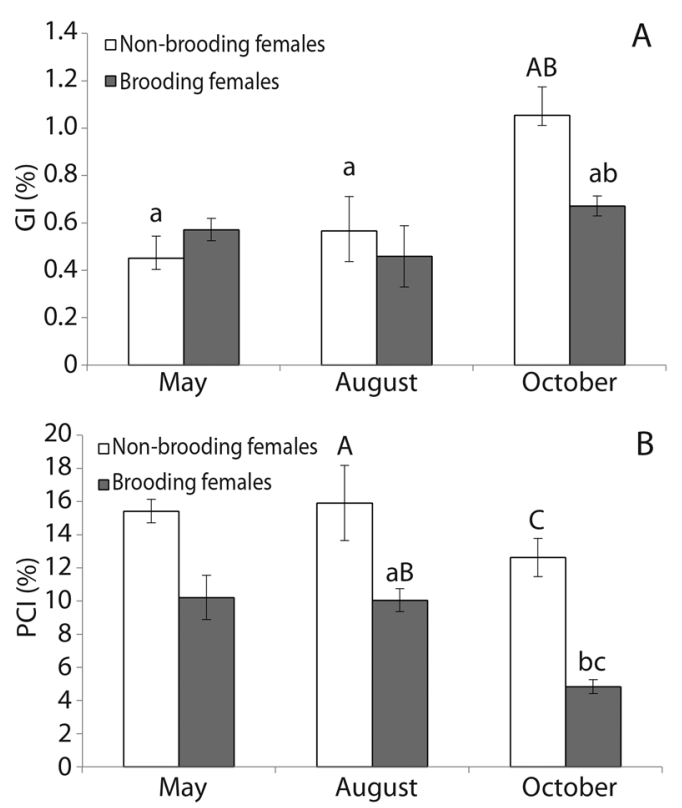

Fig. 4. Seasonal variation in females of Anasterias antarctica during the brooding period. A. Gonad index (GI); B, Pyloric caeca index (PCI). Mean and SEM (Barr= standard error of mean). Only significant differences are indicated by the same capital and small letter.

Fig. 4. Variación estacional en hembras de Anasterias antarctica durante el periodo de incubación. A, Índice gonadal (GI); B, Índice de ciego pilórico (PCI). Media y ESM (Barra= error estándar de la media). Solo las diferencias significativas son indicadas con pares de la misma letra, en minúscula y mayúscula.

Occurrence of Dendrogaster argentinensis: Prevalence of $D$. argentinensis in $A$. antarctica was $11.06 \%$, all were found in the coelomic cavity of sea stars. Males, brooding, non-brooding and mature females had parasites. All specimens without gonads were parasitized (Table 1).

\section{DISCUSSION}

The studied population of Anasterias antarctica presented approximately 1:1 sex and reproductive condition ratio (non-brooding females/brooding females and non-mature females/mature female). This agrees with the results found for A. antarctica from Ría de Puerto Deseado (Santa Cruz, Argentina) (Salvat, 1985) and Península Foca (Santa Cruz,
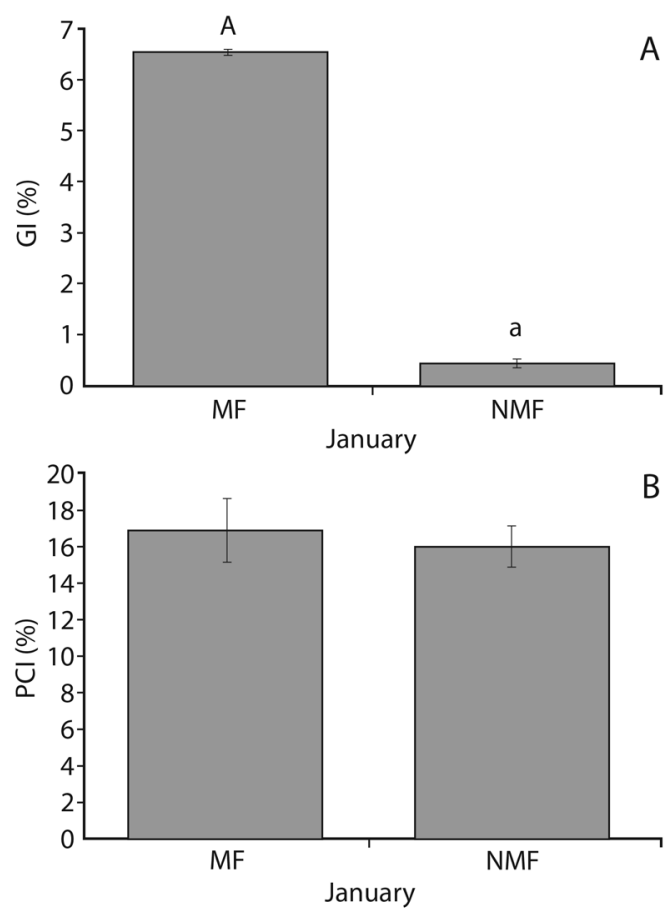

Fig. 5. Variation in females of Anasterias antarctica during the non-brooding period. A, Gonad index (GI); B, Pyloric caeca index (PCI). Mean and SEM (Barr= standard error of mean). Only significant differences are indicated by the same capital and small letter. MF: mature females. NMF: non mature females.

Fig. 5. Variación en hembras de Anasterias antarctica durante el periodo de no-incubación. A, Índice gonadal (GI); B, Índice de ciego pilórico (PCI). Media y ESM (Barra $=$ error estándar de la media). Solo las diferencias significativas son indicadas con pares de la misma letra, en minúscula y mayúscula. MF: hembra madura. NMF: hembra no madura.

Argentina) where brooding females represented almost $25 \%$, and suggesting that $50 \%$ of females were incubating (Gil \& Zaixso, 2007). In addition, brooding females in Golfo San Jorge (Patagonia, Argentina) reached 50\% during maximum incubation month, indicating that about $100 \%$ of the females were incubating (sex ratio 1:1) (Gil et al., 2011).

Brooding in $A$. antarctica from Beagle Channel occurs during the coldest months of the year (austral winter), as it was reported for other populations (Gil et al., 2011; Laptikhovsky et al., 2015) and also for other 


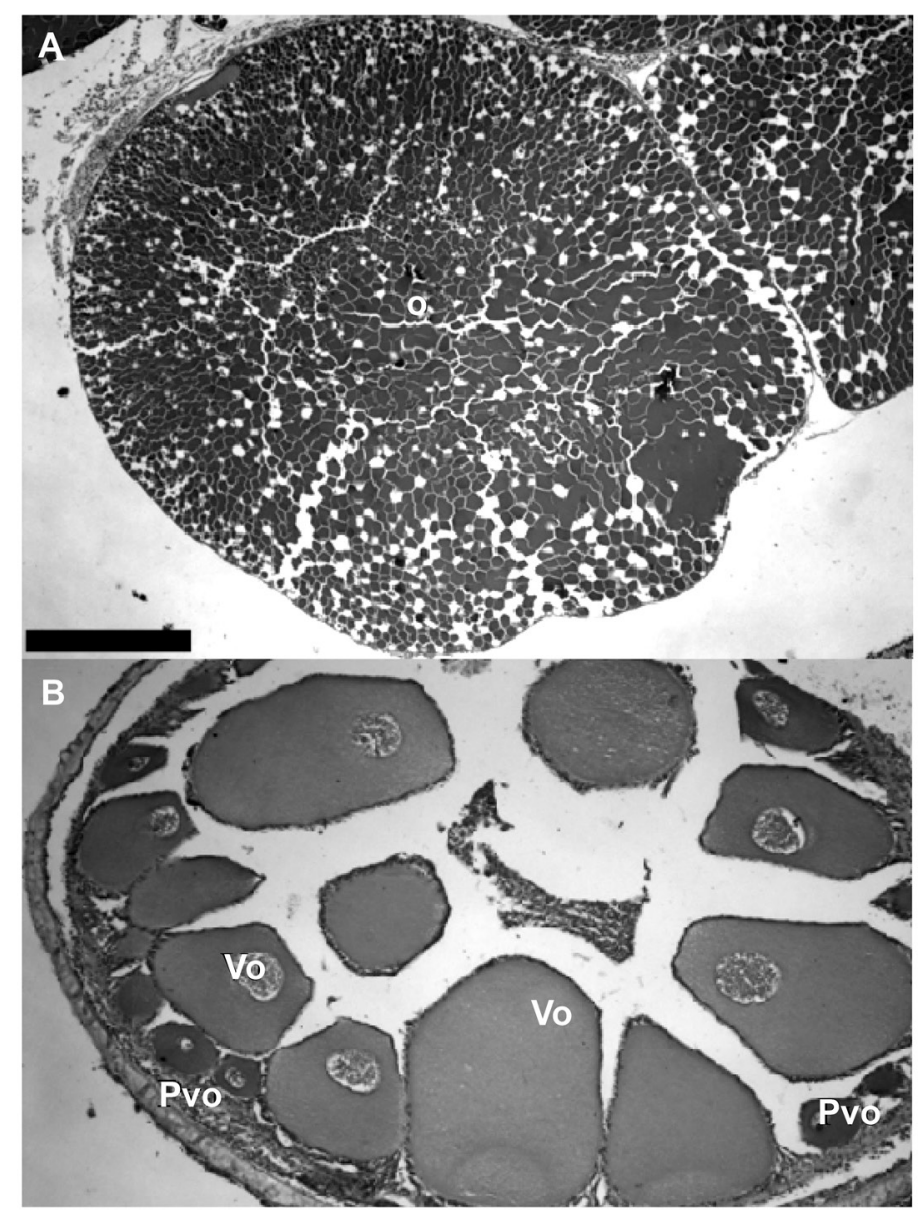

Fig. 6. Photomicrographs of gonads of Anasterias antarctica. A mature female and B non-mature female. O ova, Pvo previtellogenic oocytes, Vo vitellogenic oocytes. Barr $=500$ and $100 \mu \mathrm{m}$, respectively.

Fig. 6. Fotomicrografia de gónadas de Anasterias antarctica. A hembra madura y B hembra no-madura. O ova, Pvo oocitos previtelogénicos, Vo oocitos vitelogénicos. Barra $=500$ y $100 \mu \mathrm{m}$, respectivamente.

asteroid such as Leptasterias polaris (Himmelman et al., 1982) and Leptasterias tenera (Hendler \& Franz, 1982). During brooding and non-brooding period, there were females in two reproductive conditions simultaneously. Through the brooding period there were brooding and non-brooding females and which showed relatively lower GI values in relation to the average GI recorded in summer (nonbrooding period) (Fig. 4A). Towards the end of the brooding period, non-brooding females showed a significantly higher GI than the brooding females. Similar results were reported by Bosch \& Slattery (1999) for the antarctic sea star Neosmilaster georgianus and by Gil \& Zaixso (2007) for Anasterias antarctica. This can be explained by histological observations of $A$. antarctica ovaries due to the proliferation and the increase of the oocytes size (vitellogenic oocytes) of the non-brooding females, while the ovaries of brooding females either had no oocytes or had small previtellogenic oocytes.

Once the brooding period was over, there were two reproductive conditions found in females during the non-brooding period: mature females and non-mature females (Fig. 5A). Mature females $6.5 \%$ GI showed histologically mature oocytes (Fig. 6A), which 
TABLE 1

Prevalence (\%) of Dendrogaster argentinensis parasitizing Anasterias antarctica. $\mathrm{N}_{\text {tot }}$ : number of individuals by sex and female stages

CUADRO 1

Prevalencia (\%) de Dendrogaster argentinensis parasitando Anasterias antarctica. $N_{\text {tot }}:$ numero de individuos por sexo y estadios femeninos

\begin{tabular}{lcc}
\multicolumn{1}{c}{ Sex } & $\mathrm{N}_{\text {tot }}$ & Prevalence (\%) \\
Males & 47 & 10.64 \\
Female & 65 & 7.69 \\
$\quad$ Brooding female & 22 & 9.09 \\
Non brooding female & 30 & 6.67 \\
Mature female & 6 & 16.67 \\
Non mature female & 7 & 0 \\
Without gonads & 4 & 100 \\
\hline
\end{tabular}

could be spawned and fertilized by the end of the summer, while the GI from the non-mature females remained relatively low (approximately $0.5 \%$ ) exhibiting mainly previtelogenic oocytes (Fig. 6B). Therefore the females that didn't brood (non-brooding females) present an active gametogenesis reaching the summer with a high GI and becoming mature females, whereas the females that have brooded (brooding females) would not have enough energy to grant a new gonadal maturation during summer, and a new incubation. Though more frequent samples are necessary we suggest that would become mature (non-brooding) females during following summer taking then two years to complete the oogenesis cycle Increased GI in males and mature females during summer coincides with a maximum gonadal development and maturation of the gametes (Figs. 3a, 5a and 6). This result agrees with Salvat (1985) and Gil \& Zaixso (2007) where they suggest that spermatogenesis has an annual cycle while oogenesis could be a biennial cycle in $A$. antarctica. Unlike the observed in females, the males showed synchronicity in the reproductive condition, maintaining GI values around 1-2\% during May, August and October and increasing significantly in January (Fig. 3a) when all males were sexually mature. GI maximum values reported here were lower than those reported for Neosmilaster georgianus (Bosch \& Slattery, 1999) and similar to those reported for Leptasterias polaris (Raymond et al., 2004). This difference in the synchronicity between sexes would be interpreted as a consequence of highly differential energetic costs of reproduction of $A$. antarctica at high latitudes, which imposes only to females a biannual cycle.

The pyloric caeca work as a reserve of energy, located inside the arms of the asteroids, and an indicator of the individuals energy reserves is the size and concentration of lipid present on it (Giese, 1966; Lawrence, 1987b). Bosch \& Slattery (1999), McClintock \& Pearse (1987) and McClintock (1989) reported for a high accumulation of pyloric caeca lipids for the antarctic sea stars Neosmilaster georgianus, Diplasterias brucei and Notasterias armata which may provide easily metabolized energy stores for the incubation period.

The PCI in Anasterias antarctica remained constant through the study in males, nonbrooding females, mature females and nonmature females (Figs. 3b, 4b and 5b), being approximately $15 \%$. Significantly lower PCI values were recorded in brooding females from the middle to the end of the brooding period, reaching nearly $5 \%$ (Fig. $4 \mathrm{~b}$ ). This is due to the brooder's inability to feed during incubation because the embryos mass is located over the mouth. Likewise, it is important to highlight that both the population of $A$. antarctica here studied, and $N$. georgianus (Bosch \& Slattery, 1999) were never observed feeding while brooding. It is possible to conclude that the pyloric caeca is performing the role of a reserve organ in the brooding females, decreasing its mass during the brooding period. Acordding to this results, Cerda, Flores, Zaixso \& Córdoba, (2016) reported carbohydrates of pyloric caeca and the body wall as reserve substances to endure the periods of long-term starvation of brooding females or those of reduced consumption rates of non-brooding females and males. During summer, both mature and nonmature females showed a high PCI (aproximately $15 \%$ ), leading to conclude that both 
groups have fed and destined energy to pyloric caeca, in accordance with the maximum feeding activity found before and after the reproductive period of $A$. antarctica in Malvinas Islands by Laptikhovsky et al. (2015).

Constancy in PCI values in both sexes and the different reproductive conditions (except in brooding females) suggests that the food of A. antarctica's in the Beagle Channel could be available throughout the year that should be confirmed almost by increasing samplings. Bosch and Slattery (1999) found that N. georgianus PCI descending in brooding females while the incubation proceeds and not confirming differences between PCI values of males and non-brooding females, suggesting a similar pattern than those reported here.

Hendler \& Franz (1982) reported a cesation of feeding during brooding period toghether with a decline in pyloric caeca supply in Leptasterias tenera. Raymond et al. (2004) described in Leptasterias polaris that the PCI descends both in males and females; in males this decrease was during the gametogenesis while in females during the months of incubation as it was observed in A. antactica. Gil \& Zaixso (2007) observed a decrease in the PCI and the feeding rate in Anasterias antarctica durig winter.

Our findings reinforce the idea that the reproductive effort differ between sexes in brooding (Chia, 1969). Males invest considerably more effort in gamete production than females, adopting a strategy characteristic of broadcast spawning species, while females assume a strategy that is more characteristic of brooders as described by other authors (Raymond et al., 2004; Mercier \& Hamel, 2008).

Even though the reproductive effort of female $A$. antarctica is $25 \%$ higher than in males (Pérez et al., 2015), males gametes production is higher, as reflected in the IG values (Figure 3a, 4a). Females reproductive effort is higher due to the long starvation they suffer during the brooding period (Pérez et al., 2015), wich is evidenced in the decrease of the energetic reserves of the pyloric caeca in the brooding females from the middle to the end of the brooding period in concordance with Gil \& Zaixso 2007.

The overall prevalence of $D$. argentinensis in $A$. antarctica was high (about $11 \%$ ), compared to the $1.5 \%$ of $A$. antarctica infested in Ría de Puerto Deseado (Santa Cruz, Argentina) (Salvat, 1985), Golfo San Jorge (Patagonia, Argentina) (Gil, pers. comm.) and 3\% in Península Foca,(Santa Cruz, Argentina) (Gil, pers. Comm.). In host populations with a high prevalence of infection, parasitic castration may negatively affect their reproductive potential unless there are mechanisms that compensate for reproductive losses. For example, the prevalence of $D$. argentinensis was over $90 \%$ in Allostichaster insignis on Otago and the castration resulted in an increase in the incidence of asexual reproduction among larger individuals (Palmer, 1997). In this study, D. argentinensis was recorded in $100 \%$ of the sea stars lacking gonads therefore these infected hosts could have been castrated (prevalence was $11.06 \%$ and $28 \%$ of them did not presented gonads). However, comprehensive investigations are needed to understand the effect of this parasite on the reproduction of $A$. antarctica.

Finally, it is possible to assert the importance of the pyloric caeca as a reserve organ in the brooding females especially in species where feeding is impossible during incubation period. Moreover, due to this impossibility of feeding by females throughout this period reproductive effort is higher than in males, confirming that the reproductive effort differ between sexes in brooding species.

\section{ACKNOWLEDGMENT}

This study was supported by grants from ANPCyT, CONICET (PIP 0128 and PICT 1270), Fundación Científica Felipe Fiorellino and University of Maimónides. Authors are grateful to the members of Laboratorio de Ecología, Fisiología y Evolución de Organismos Acuáticos (CADIC-CONICET) and particularly to D. Aureliano, M. Gutierrez and S. Rimbau for technical assistance. 


\section{RESUMEN}

La estrella de mar incubadora Anasterias antarctica se distribuye desde la costa Patagónica hasta el norte de la Península Antártica. En el Canal Beagle, las hembras de $A$. antarctica incuban sus huevos durante 7 meses y no se alimentan durante este periodo. El endoparásito Dendrogaster argentinensis (Crustacea: Ascothoracica) ha sido encontrado en varias especies del genero Anasterias y se ha reportado que causan castración. Individuos adultos fueron recolectados en cuatro muestreos al azar durante mayo, agosto y octubre (periodo de incubación) y en enero (periodo de no incubación). El índice gonadal (GI) y de ciego pilórico $(\mathrm{PCI})$ fueron calculados como peso húmedo del órgano $(\mathrm{g})$ x 100/peso húmedo total $(\mathrm{g})$. Cada individuo fue sexado mediante la observación microscópica de las gónadas. La prevalencia de $D$. argentinensis también fue estimada. La proporción de sexos, de hembras incubantes/ hembras no incubantes y de hembras maduras/hembras no maduras no difirió significativamente de 1:1. El GI máximo de los machos fue registrado en enero, cuando la mayoría de los individuos se encontraban sexualmente maduros. El GI de las hembras no incubantes fue máximo durante octubre, y mayor que el de las hembras incubantes. El PCI fue mínimo en octubre, siendo menor en las hembras incubantes que en las hembras no incubantes (agosto y octubre). Durante el periodo de no incubación, las hembras maduras presentaron un GI significativamente mayor que las hembras no maduras. El PCI no varió ni entre machos, ni entre hembras maduras y no maduras. Hacia el final del periodo de incubación, las hembras no incubantes mostraron un GI mayor que las hembras incubantes, pudiéndose explicar por la proliferación y aumento de tamaño de los oocitos en las hembras no incubantes. Las hembras maduras presentaron un incremento del GI con presencia de oocitos maduros mientras que en las hembras no maduran predominaron los oocitos previtelogénicos. Los machos mostraron sincronicidad en la condición reproductiva. Las hembras que no incubaron presentaron un proceso de gametogénesis activa, alcanzando el verano con un elevado GI y convirtiéndose en hembras maduras. Las hembras que incubaron, probablemente no tuvieron la energía suficiente para una nueva maduración gonadal. Los ciegos pilóricos podrían presentar función de órgano de reserva en las hembras incubantes, disminuyendo su tamaño durante el periodo de incubación. La prevalencia de $D$. argentinensis en $A$. antarctica fue de $11.06 \%$. Como los parásitos fueron registrados en estrellas de mar sin gónadas, estos huéspedes infectados podrían haber sido castrados.

Palabras claves: estrella de mar incubadora; gónada; ciego pilórico; órgano de reserva; endoparásito.

\section{REFERENCES}

Barker, M. F., \& Xu, R. A. (1991). Seasonal changes in biochemical composition of body walls, gonads and pyloric caeca in two populations of Sclerasterias mollis (Echinodermata: Asteroidea) during the annual reproductive cycle. Marine Biology, 109, 27-34.

Bernasconi, I. (1964). Distribución geográfica de los Equinoideos y Asteroideos de la extremidad austral de Sudamérica. Boletín del Instituto de Biología Marina, 7, 43-50.

Blankley, W. O., \& Branch, G. M. (1984). Co-operative prey capture and unusual brooding habits of Anasterias rupicola (Verrill) (Asteroidea) at sub-Antarctic Marion Island. Marine Ecology Progress Serie, 20, 171-176.

Bosch, I., \& Slattery, M. (1999). Costs of extended brood protection in the Antarctic sea star, Neosmilaster georgianus (Echinodermata: Asteroidea). Marine Biology, 134, 449-459.

Brockington, S., Clarke, A., \& Chapman, A. G. (2001). Seasonality of feeding and nutritional status during the austral winter in the Antarctic sea urchin Sterechinus neumayeri. Marine Biology, 139, 127-138.

Bush, A. O., Lafferty, K. D., Lotz, J. M., \& Shostak, A. W. (1997). Parasitology meets ecology on its own terms: Margolis et al. Revisited. Journal of Parasitology, 575-583.

Cerda, R. C., Flores, M. L., Zaixso, H. E., \& Córdoba, O. L. (2016). Analysis of carbohydrates in breeding females of the sea star Anasterias minuta Perrier 1875. Metabolic interrelations between different organs and the brooding process. Journal of Marine Biological Association of the United Kingdom, 1-6.

Clark, A., \& Downey, M. (1992). Starfish of the Atlantic. An Illustrated Key. Cambridge: Koeltz Scientific Books.

Cossi, P. F., Boy, C., Giménez, J., \& Pérez, A. (2015). Reproductive biology and energy allocation of the sea star Cosmasterias lurida (Echinodermata: Asteroidea) from the Beagle Channel, Tierra del Fuego, Argentina. Polar Biology. doi: 10.1007/s00300-015-1696-x

Curelovich, J. N. (2012). Mecanismos reguladores de la estructura y dinámica de la comunidad intermareal rocosa de Ensenada Zaratiegui, Tierra del Fuego. (Tesis Doctoral), Universidad de Buenos Aires, Agentina.

Chia, F. S. (1968). Some observations on the development and cyclic changes of the oocites in brooding starfish Leptasterias hexactis Journal of Zoology, 154, 453-461.

Chia, F. S. (1969). Histology of the pyloric caeca and its changes during brooding and starvation in a starfish Leptasterias hexactis. Biology Bulletin, 136, 185-192.

Chia, F. S., \& Walker, C. W. (1991). Echinodermata: Asteroidea. In A. C. Giese, J. S. Pearse \& V. B. Pearse (Eds.), Reproduction of marine invertebrates: VI. 
Echinoderms and lophophorates (pp. 301-331). California: Boxwood Press.

Dunne, J. A., Lafferty, K. D., Dobson, A. P., Hechinger, R. F., Kuris, A. M., Martinez, N. D., Reise, K. (2013). Parasites affect food web structure primarily through increased diversity and complexity. PLOS Biology, 11(6).

Giese, A. C. (1966). On the biochemical constitution of some echinoderms. In R. A. Boolootian (Ed.), Physiology of echinodermata (pp. 757-796). New York: Interscience.

Gil, D. G., \& Zaixso, H. E. (2007). The relation between feeding and reproduction in Anasterias minuta (Asteroidea: Forcipulata). Marine Biology Research, 3(4), 256-264. doi: 10.1080/17451000701472035

Gil, D. G., \& Zaixso, H. E. (2008). Feeding ecology of the subantarctic sea star Anasterias minuta within tide pools in Patagonia, Argentina. Revista de Biología Tropical, 56:311-328

Gil DG, Escudera G, Zaixso HE (2011) Brooding and development of Anasterias minuta (Asteroidea: Forcipulatida) in Patagonia, Argentina. Marine Biology, 158, 2589-2602.

Gillespie, J. M., \& McClintock, J. B. (2007). Brooding in echinoderms: How can modern experimental techniques add to our historical perspective? $J \operatorname{Exp}$ Mar Biol Ecol, 342(2), 191-201. doi: 10.1016/j. jembe.2006.10.055'

Grygier, M. J. (1986). Dendrogaster (Crustacea: Ascothoracida) parasitic in Alaskan and eastern Canadian Leptasterias (Asteroidea). Canadian Journal of Zoology, 64(6), 1249-1253.

Grygier, M. J., \& Salvat, M. B. (1984). Dendrogaster argentinensis, new species, a south american sea-star parasite (Crstacea: ascothoracida). Proceedings of the Biological Society of Washington, 97(1), 43-48.

Hamel, J. F., \& Mercier, A. (1995). Prespawning behavior, spawning, and development of the brooding starfish Leptasterias polaris. Biology Bulletin, 188, 32-45.

Hendler, G., \& Franz, D. R. (1982). The biology of a brooding seastar, Leptasterias tenera, in Block Island Sound. Biology Bulletin, 162, 273-282.

Himmelman, J. H., Lavergne, Y., Cardinal, A., G, G. M., \& Jalbert, P. (1982). Brooding behaviour of the northern sea star Leptasterias polaris. Marine Biology, $68,235-240$.

Kubo, K. (1951). Some observations on the development of the sea-star, Leptasterias ochotensis similispinis (Clark). Journal Of The Faculty Of Science Hokkaido University Series V. I. Zoology, 10(2), 97-105.
Lafferty, K. D., Dobson, A. P., \& Kuris, A. M. (2006). Parasites dominate food web links. Proceedings of the National Academy of Sciences, 103(30), 11211-11216.

Laptikhovsky, V., Brickle, P., Söffker, M., Davidson, D., Roux, M. J., Rexer-Huber, K., Brewin, P. E., Kälkvist, E., Brown, J., Brown, S., Black, A., Anders, N. R., Cartwright, S., Poncet, D., Parker, G. (2015). Life history and population characteristics of the Antarctic starfish, Anasterias antarctica Lütken, 1856 (Asteroidea: Forcipulatida: Asteriidae) around the Falkland Islands. Polar Biology, 463-474

Lawrence, J. M. (1987a). Echinoderms. In T. J. Pandian \& F. J. Vernberg (Eds.), Animal energetics (Vol. 2, pp. 229-321). San Diego: Academic Press.

Lawrence, J. M. (1987b). A functional biology of echinoderms London: Croom Helm

Lawrence, J. M., \& McClintock, J. B. (1994). Energy acquisition and allocation by echinoderms (Echinodermata) in polar seas: adaptations for success? In B. David, A. Guille, J. P. Fe'ral \& M. Roux (Eds.), Echinodermata (pp. 39-52). Rotterdam: Balkema.

Lucas, A. (1996). Energetics of aquatic animals. Taylor and Francis Press.

Lloret, J., \& Planes, S. (2003). Condition, feeding and reproductive potential of white seabream Diplodus sargus as indicators of habitat quality and the effect of reserve protection in the northwestern Mediterranean. Marine Ecology Progress Serie, 248, 197-208.

Mariante, F. L. F., Lemos, G. B., Eutrópio, F. J., Castro, R. R. L., \& Gomes, L. S. (2010). Reproductive biology in the starfish Echinaster (Othilia) guyanensis (Echinodermata: Asteroidea) in southeastern Brazil. Zoologia, 27(6), 897-901. doi: 10.1590/ S1984-46702010000600010

McClintock, J. B. (1989). Energetic composition, reproductive output, and resource allocation of antarctic asteroids. Polar Biology, 9, 147-153.

McClintock, J. B., \& Pearse, J. S. (1987). Biochemical composition of antarctic echinoderms. Comparative Biochemistry and Physiology, 86, 683-687.

Mercier, A., \& Hamel, J.-F. (2008). Depth-related shift in life history strategies of a brooding and broadcasting deep-sea asteroid. Marine Biology, 156(2), 205-223. doi: 10.1007/s00227-008-1077-x

Palmer, P. L. (1997). A new species of ascothoracid parasite (Maxillopoda) from the Otago Shelf, New Zealand, and a new host record. Crustaceana, 769-779.

Palmer, P. L. (2009). The biology of Dendrogaster (Crustacea, Ascothoracida), parasitic in sea stars from Otago, New Zealand. University of Otago. 
Pérez, A., Boy, C., Morriconi, E., \& Calvo, J. (2010). Reproductive cycle and reproductive output of the sea urchin Loxechinus albus (Echinodermata: Echinoidea) from Beagle Channel, Tierra del Fuego, Argentina. Polar Biology, 33, 271-280.

Pérez, A., Morriconi, E., Boy, C., \& Calvo, J. (2008) Seasonal changes in energy allocation to somatic and reproductive body components of the common cold temperature sea urchin Loxechinus albus in a SubAntarctic environmet. Polar Biology, 31, 443-449.

Pérez, A. F., Boy, C. C., Calcagno, J., \& Malanga, G. (2015). Reproduction and oxidative metabolism in Anasterias antarctica, a brooding sea star. Journal of Experimental Marine Biology and Ecology, 463, $150-157$.

Raymond, J. F., Himmelman, J. H., \& Guderley, H. E. (2004). Sex differences in biochemical composition, energy content and allocation to reproductive effort in the brooding sea star Leptasterias polaris. Marine Ecology Progress Serie, 283, 179-190.

Raymond, J. F., Himmelman, J. H., \& Guderley, H. E. (2007). Biochemical content, energy composition and reproductive effort in the broadcasting sea star Asterias vulgaris over the spawning period. Journal of
Experimental Marine Biology and Ecology, 341(1), 32-44. doi: 10.1016/j.jembe.2006.10.030

Romanelli-Michel, M. V. (2014). Revisión taxonómica de las estrellas de mar de la familia Asteriidae Gray, 1840 (Asteroidea: Forcipulatida) del Atlántico Sudoccidental. (PhD Thesis), Universidad de Buenos Aires, Buenos Aires, Argentina.

Salvat, M. B. (1985). Biología de la reproducción de Anasterias minuta Perrier (Echinodermata, Asteroidea), especie incubadora de las costas patagonicas. (PhD), Universidad de Buenos Aires, Buenos Aires, Argentina.

Sokal, R. R., \& Rohlf, J. (1995). Biometry. The principles and practice of statistics in biological research, 3rd edn. WH Freeman and Company, New York

Strathmann, R. R., Strathmann, M. F., \& Emson, R. H. (1984). Does Limited Brood Capacity Link Adult Size, Brooding, and Simultaneous Hermaphroditism? A Test with the Starfish Asterina phylactica. The American Naturalist, 123(6), 796-818.

Zar, J. H. (1984). Biostatistical analysis. New York: Prentice-Hall. 